\title{
PENGGUNAAN METODE PROFILE MATCHING UNTUK SISTEM PENUNJANG KEPUTUSAN KENAIKAN JABATAN PADA INSTANSI PEMERINTAH
}

\author{
Frieyadie \\ Program Studi Manajemen Informatika \\ AMIK BSI Jakarta \\ Jl. Kramat Raya no 18 Jakarta Pusat \\ frieyadie@bsi.ac.id
}

\begin{abstract}
Findings problems are detected, such as: Still the ratings unilaterally cause social jealousy and judgment becomes objective. There is still no effective assessment make judgments solely based on certain criteria. The purpose of this study is to: Build a decision support system that can help the relevant agencies to provide recommendations for decision-making and judgment in determining which employees will be promoted later to be given the post. Improving the quality of research, thereby reducing errors in melolosakan prospective employees that are not in accordance with the standards of quality positions at the agency. Profile Matching methods used to solve problems in this study. The results of the calculation Profile Matching stated that the alternative selected and the most appropriate criteria are employee-2 (P2) with the results Profile Matching stated that the alternative selected and the most appropriate criteria are employee-5 (P5) with the results Profile Matching obtained of the questionnaire by the three respondents gave the answer can be calculated and the final result that the employee-5 (P5) of 4.15 compared with employees excel-1 $(P 1)$ of 4.06, an employee-4 (P4) with a value of 4.02, employee-3 (P3) of 3.88 , and an employee-2 (P2) of 3.85
\end{abstract}

Keywords: Metode Profile Matching, Decision Support System, The increase Position

\section{PENDAHULUAN}

Kenaikan jabatan merupakan salah satu faktor yang sangat penting bagi perencanaan karir pegawai dan juga untuk meremajakan suatu posisi jabatan agar diduduki oleh seseorang yang mempunyai kriteria-kriteria yang cocok untuk menempati suatu jabatan yang diusulkan. Adapun kriteria pertama yang diusulkan yaitu, sikap kerja, dan kecerdasan yang dimiliki pegawai. Kriteria kedua yaitu tingkat pendidikan, lamanya waktu bekerja, prestasi kerja. Dengan adanya penilaian secara subyektif membuat kecemburuan sosial terhadap pegawai yang merasa kurang adil terhadap keputusan yang berlaku. Temuan permasalahan yang terdeteksi, diantaranya: Masih adanya penilaian secara sepihak menyebabkan kecemburuan sosial dan penilaian menjadi tidak objektif atau subyektifitas dalam penilaian kinerja pegawai merupakan hal yang hampir tidak bisa dihindari Adhar (2014:17), Masih adanya penilaian yang tidak efektif membuat penilaian hanya berdasarkan pada kriteria tertentu saja dan pegawai yang langsung mendapat promosi untuk kenaikan jabatan yang hanya melihat pada kriteria pertama saja, tetapi pegawai tersebut belum tentu unggul pada beberapa kriteria-kriteria yang lain, akan tetapi tetap mendapat promosi untuk kenaikan jabatan Ananta dan Winiarti (2013:575)Tujuan dari penelitian ini untuk: Membangun sistem pendukung keputusan yang dapat membantu instansi terkait dengan memberikan rekomendasi dan pertimbangan untuk pengambilan keputusan dalam menentukan pegawai yang akan diberi kenaikan pangkat nantinya yang akan diberi jabatan. Meningkatkan kualitas penelitian sehingga mengurangi kesalahan dalam melolosakan calon pegawai yang sebenarnya tidak sesuai dengan standar kualitas posisi jabatan pada instansi.

\section{KAJIAN LITERATUR}

Dalam penelitian Muqtadir dan Purdianto (2013) mengatakan seringkali proses kenaikan jabatan dan perencanaan karir pada perusahaan hanya didasarkan pada faktor tertentu saja, yaitu tingkat pendidikan, lamanya waktu bekerja dan golongan. Namun demikian masih terdapat banyak faktor lain untuk menilai sesseorang untuk proses kenaikan jabatan seperti daya tahan, ketekunan dan ketelitian atau keahlian 
yang lainnya. Tujuan yang akan dicapai dalam penelitian ini adalah : 1) Membuat sebuah SPK kenaikan jabatan di PT. IKSG dengan menggunakan metode profile matching. 2) Membantu pengambil keputusan yang kesulitan dalam memutuskan karyawan yang cocok untuk menempati suatu jabatan tertentu. Berdasarkan hasil penelitian yang telah diuraikan diatas, maka dapat diambil beberapa kesimpulan sebagai berikut : 1). Promosi kenaikan jabatan yang ada di PT. IKSG tidak lagi hanya mengandalkan tingkat pendidikan, masa kerja serta golongan, namun juga mempertimbangkan factor pengetahuan serta budaya perusahaan, kemampuan dan keahlian serta kepribadian karyawan. 2) Pemilihan kriteria dan variabel penilaian serta penentuan standar nilai untuk setiap profil jabatan sangat berpengaruh dalam proses seleksi karyawan. 3) Sistem pendukung keputusan dengan metode profile matching terbukti mampu mengolah data masukan berupa data jabatan, data karyawan dan data bobot variabel menjadi sebuah proses penilaian karyawan yang akan dipromosikan sehingga proses seleksi karyawan untuk jabatan baru menjadi lebih cepat dan akurat.

Penelitian yang dilakukan oleh Hartatik (2013), menyatakan dalam pemilihan karyawan pada kenyataannya merupakan proses kegiatan rutinitas yang sangat kompleks, memakan waktu yang cukup lama, biaya yang tidak sedikt dan sangat terbuka peluang untuk melakukan kesalahan dalam menentukan orang yang tepat. Manfaat dari penelitian yang dilakukannya memberi alternatif keputusan yang dapat membantu PT. DOK Kodja Bahari dalam memilih pegawai untuk menduduki posisi jabatan yang tepat secara objektif. Penelitian yang dilakukan menggunakan metode profile matching. metode ini digunakan dalam penilaian seleksi pemilihan pegawai, yang dapat memberikan penilaian potensi masingmasing kandidat karyawan dengan melakukan perbandingan profil pribadi karyawan dengan profil jabatan yang bersangkutan.

\section{METODE PENELITIAN}

\section{A. Rancangan Penelitian}

Rancangan penelitian diawali dengan rumusan masalah didapat dari identifikasi masalah yang ada dan berkembang saat ini
Penentuan Kenaikan Jabatan Pegawai pada Ditjen Pengendalian Pemanfaatan Ruang dan Penguasaan Tanah Kementerian Agraria dan Tata Ruang.

Pengambilan data dengan menggunakan teknik observasi, dimana dilaksanakan dengan melihat keadaan didalam suatu divisi dan proses berjalannya kenaikan jabatan pada Ditjen Pemanfaatan Ruang dan Penguasaan Tanah Kementerian Agraria dan Tata Ruang, kemudian juga dengan menggunakan teknik wawancara, untuk mengambil hal-hal yang berkaitan dengan kenaikan jabatan pegawai dan memberikan lembar angket/kuesioner kepada kepala bagian divisi yang bersangkutan untuk kenaikan jabatan.

Penentuan kriteria-kriteria dari Sistem Penunjang Keputusan menggunakan Profile Matching dalam menentukan kenaikan jabatan pegawai diantaranya Kesetiaan, Prestasi Kerja, Tanggung Jawab, Ketaatan, Kejujuran, Kejasama, Prakarsa, Kepemimpinan, Tingkat Pendidikan, dan Pengalaman Kerja. Kemudian menentukan data-data yang dibutuhkan berdasarkan populasi, sampel dan cara pengambilan sampel. Kemudian menentukan objek peneliti.

Metode pengumpulan data yang dilakukan peneliti terbagi menjadi 2 cara, yaitu: a) Data Primer dengan melakukan observasi langsung, wawancara, dan kuesioner. b) Data sekunder berasal dari mengumpulkan dan mengidentifikasi serta mengolah data tertulis berbentuk buku-buku dan jurnal yang berkaitan dengan penelitian.

Populasi akan diambil pada salah satu divisi yang sedang memiliki 1 (satu) ketersediaan posisi untuk dapat melakukan kenaikan jabatan dari posisi staff menjadi kepala sub bagian sebanyak 1 orang. Dari populasi tersebut akan diambil 3 sampel.

Dalam pemilihan sampel, penulis mengambil data dari populasi yang terbatas dengan menyebarkan kuesioner kepada kepala sub bagian setempat untuk melakukan penilaian dikarenakan penilaian dilakukan oleh PNS dengan golongan $3 b$ yang berarti PNS yang sudah mengabdi selama lebih dari 4 tahun.

\section{B. Metode Analisa Data}

Metode pemecahan masalah yang digunakan metode Profile Matching, dimana sebuah mekanisme pengambilan keputusan dengan mengasumsikan bahwa terdapat tingkat variabel prediktor yang ideal yang 
harus dimiliki oleh pelamar, bukannya tingkat minimal yang harus dipenuhi atau dilewati. Kusrini (2007:53).

Dalam pencocokan profil, dilakukan identifikasi terhadap kelompok karyawan yang baik maupun yang buruk. Para karyawan dalam kelompok tersebut diukur menggunakan beberapa kriteria penilaian.

Tahapan dalam metode profile matching adalah sebagai berikut :

1. Menentuan Bobot Nilai Gap. Pada tahap ini, akan ditentukan bobot nilai masingmasing aspek dengan menggunakan bobot nilai yang telah ditentukan bagi masing-masing aspek itu sendiri. Adapun inputan dari proses pembobotan ini adalah selisih dari profil karyawan dan profil jabatan.

2. Langkah kedua dengan melakukan pemetaan Gap. Gap yang dimaksud adalah perbedaan antara profil pegawai dengan profil jabatan.

3. Melakukan pencocokan dengan tabel bobot Gap Hasil Gap dari pengurangan profil karyawan dan profil jabatan bila dicocokkan dengan kolom selisih gap pada table bobot nilai yang dihasilkan sama.

4. Melakukan perhitungan core factor dan secondary factor. Setelah menentukan bobot nilai gap untuk ketiga aspek yang dibutuhkan, kemudian tiap aspek dikelompokkan lagi menjadi dua kelompok yaitu core factor dan secondary factor.

5. Perhitungan nilai total dengan rumus sebagai berikut: Kusrini(2007:65)

$$
\begin{aligned}
N(\boldsymbol{i}, \boldsymbol{s}, \boldsymbol{p})=(\boldsymbol{x}) \% \boldsymbol{N C F}(\boldsymbol{i}, \boldsymbol{s}, \boldsymbol{p}) \\
+(\boldsymbol{x}) \% \operatorname{NSF}(i, s, p)
\end{aligned}
$$

6. Perhitungan Penentuan Rangking dengan rumus sebagai berikut : Kusrini (2007:66)

$$
\begin{gathered}
\text { Ranking }=(x) \% \boldsymbol{N i}+(\boldsymbol{x}) \% \boldsymbol{N s} \\
+(\boldsymbol{x}) \% \boldsymbol{N p}
\end{gathered}
$$

\section{PEMBAHASAN}

Bagian hasil penelitian berisi paparan hasil analisis yang berkaitan dengan pertanyaan penelitian. Setiap hasil penelitian harus dibahas. Pembahasan berisi pemaknaan hasil dan pembandingan dengan teori dan/atau hasil penelitian sejenis. Panjang paparan hasil dan pembahasan 40$60 \%$ dari panjang artikel

\section{A. Kriteria Dalam Penentuan Kenaikan Jabatan}

Dalam hal ini penulis akan menjelaskan tentang proses perhitungan kenaikan jabatan pegawai berdasarkan metode profile matching yang mengacu pada tahapantahapan yang dijelaskan pada materi sebelumnya. Berdasarkan data yang dikumpulkan melalui interview dan kuesioner, maka setiap bagian mempunyai kriteria tersendiri dalam menentukan pegawai untuk kenaikan jabatan, kriteria tersebut adalah :

1. Kriteria pada aspek Sikap Kerja adalah sebagai berikut: Kesetiaan, Tanggung Jawab, Kejujuran, Ketaatan, Kerjasama

2. Kriteria pada aspek Kecerdasan adalah sebagai berikut: Prestasi kerja, Prakarsa, Kepemimpinan

3. Kriteria pada aspek Prestasi Kerja adalah sebagai berikut: Kecakapan, Ketrampilan, Pengalaman, Kesungguhan

4. Kriterian pada aspek Pendidikan adalah sebagai berikut: Pendidikan Terakhir, Kemampuan, Lama Bekerja.

\section{B. Standar Penilaian Per Kriteria Dalam Bagian}

Berdasarkan hasil interview ke masingmasing bagian, maka setiap kriteria dalam bagian mempunyai bobot masing-masing. Berikut adalah bobot masing-masing kriteria dalam tiap aspek:

\section{Aspek Sikap Kerja}

Hal-hal yang diukur dari aspek ini adalah Kesetiaan, Tanggung Jawab, Kejujuran, Ketaatan, dan Kerja Sama.

Tabel 1. Hasil Sikap Kerja

\begin{tabular}{ccccccc}
\hline \multirow{2}{*}{ No } & $\begin{array}{c}\text { Kode } \\
\text { Pegawai }\end{array}$ & $\begin{array}{c}\text { SK1 } \\
(\mathrm{A})\end{array}$ & $\begin{array}{c}\text { SK2 } \\
(\mathrm{B})\end{array}$ & $\begin{array}{c}\text { SK3 } \\
(\mathrm{C})\end{array}$ & $\begin{array}{c}\text { SK4 } \\
(\mathrm{D})\end{array}$ & $\begin{array}{c}\text { SK5 } \\
(\mathrm{E})\end{array}$ \\
\hline 1 & Pegawai-1 & 3 & 2 & 4 & 3 & 3 \\
\hline 2 & Pegawai-2 & 2 & 3 & 3 & 4 & 2 \\
\hline 3 & Pegawai-3 & 3 & 3 & 3 & 2 & 3 \\
\hline 4 & Pegawai-4 & 4 & 3 & 3 & 3 & 2 \\
\hline 5 & Pegawai-5 & 3 & 4 & 3 & 2 & 3 \\
\hline
\end{tabular}

Sumber: Hasil Pengolahan (2016)

Keterangan:

SK1: Kesetiaan

SK2: Tanggung jawab

SK3: Kejujuran

SK4: Ketaatan

SK5: Kejasama 


\section{Aspek Kecerdasan}

Hal-hal yang diukur dari aspek ini adalah prestasi kerja, prakarsa, dan kepemimpinan.
P3: Lama Bekerja

\section{Pencarian Nilai GAP}

Untuk mencari nilai gap, dengan menggunakan rumus:

Tabel 2. Hasil Kecerdasan

GAP = Nilai Pegawai - Nilai Standar

\begin{tabular}{ll}
\hline No & $\begin{array}{c}\text { Kode } \\
\text { Pegawai }\end{array}$ \\
\hline 1 & Pegawai-1 \\
\hline 2 & Pegawai-2 \\
\hline 3 & Pegawai-3 \\
\hline 4 & Pegawai-4 \\
\hline 5 & Pegawai-5 \\
\hline Sumber: Hasil Peng \\
Keterangan: \\
K1: Prestasi Kerja \\
K2: Prakarsa \\
K3: Kepemimpinan
\end{tabular}

\section{Aspek Prestasi Kerja}

Hal-hal yang diukur dari aspek ini adalah Kecakapan, ketrampilan, pengalaman dan kesungguhan.

Tabel 3. Hasil Prestasi Kerja.

\begin{tabular}{cccccc}
\hline \multirow{2}{*}{ No } & $\begin{array}{c}\text { Kode } \\
\text { Pegawai }\end{array}$ & $\begin{array}{c}\text { PK1 } \\
(\mathrm{I})\end{array}$ & $\begin{array}{c}\text { PK2 } \\
(\mathrm{J})\end{array}$ & $\begin{array}{c}\text { PK3 } \\
(\mathrm{K})\end{array}$ & $\begin{array}{c}\text { PK4 } \\
(\mathrm{L})\end{array}$ \\
\hline 1 & Pegawai-1 & 4 & 3 & 3 & 4 \\
\hline 2 & Pegawai-2 & 3 & 3 & 3 & 4 \\
\hline 3 & Pegawai-3 & 2 & 3 & 3 & 4 \\
\hline 4 & Pegawai-4 & 4 & 3 & 2 & 3 \\
\hline 5 & Pegawai-5 & 4 & 3 & 3 & 3
\end{tabular}

Sumber: Hasil Pengolahan (2016)

Keterangan:

PK1: Kecakapan

PK2: Ketrampilan

PK3: Pengalaman

PK4: Kesungguhan

\section{Aspek Pendidikan}

Hal-hal yang diukur dari aspek ini adalah tingkat pendidikan dan pengalaman kerja.

Tabel 4. Hasil Pendidikan

\begin{tabular}{ccccc}
\hline No & $\begin{array}{c}\text { Kode } \\
\text { Pegawai }\end{array}$ & $\begin{array}{c}\text { P1 } \\
(\mathrm{M})\end{array}$ & $\begin{array}{c}\text { P2 } \\
(\mathrm{N})\end{array}$ & $\begin{array}{c}\text { P3 } \\
(\mathrm{O})\end{array}$ \\
\hline 1 & Pegawai-1 & 3 & 3 & 3 \\
\hline 2 & Pegawai-2 & 3 & 4 & 3 \\
\hline 3 & Pegawai-3 & 3 & 4 & 3 \\
\hline 4 & Pegawai-4 & 3 & 3 & 3 \\
\hline 5 & Pegawai-5 & 3 & 3 & 3 \\
\hline Sumber: Hasil Pengolahan $(2016)$ & &
\end{tabular}

Keterangan:

P1: Pendidikan Terakhir

P2: Kemampuan

Tabel 5. Tabel GAP

Sikap Kerja Kecerdasan $\quad$ Prestasi Kerja $\quad$ Pendidikan

No Kode Pegawai SK1 SK2 SK3 SK4 SK5 K1 K2 K3 PK1 PK2 PK3 PK4 P1 P2 P3 Ket

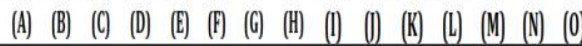

\begin{tabular}{|c|c|c|c|c|c|c|c|c|c|c|c|c|c|c|c|}
\hline $\begin{array}{ll}1 & \text { Pegawail-1 } \\
\end{array}$ & 3 & 2 & 4 & 3 & 3 & 3 & 3 & 2 & 4 & 3 & 3 & 4 & & & \\
\hline 2 Pegawail:2 & 2 & 3 & 3 & 4 & 2 & 2 & 3 & 3 & 3 & 3 & 3 & 4 & & & 3 \\
\hline 3 Pegawai-3 & 3 & 3 & 3 & 2 & 3 & 3 & 4 & 3 & 2 & 3 & 3 & 4 & & & 3 \\
\hline 4 Pegawai-4 & 4 & 3 & 3 & 3 & 2 & 3 & 3 & 2 & 4 & 3 & 2 & 3 & & & 3 \\
\hline $\begin{array}{ll}5 & \text { Pegawail.5 } \\
\end{array}$ & 3 & 4 & 3 & 2 & 3 & 3 & 4 & 4 & 4 & 3 & 3 & 3 & & & 3 \\
\hline Nilaistandar & 3 & 3 & 3 & 3 & 3 & 3 & 3 & 3 & 3 & 3 & 3 & 3 & & & + \\
\hline 1 Pegawail-1 & 0 & $\cdot 1$ & 1 & 0 & 0 & 0 & 0 & .1 & 1 & 0 & 0 & 1 & ? & & 2 \\
\hline $\begin{array}{ll}2 & \text { Pegawail-2 } \\
\end{array}$ & 1 & 0 & 0 & 1 & 1 & 1 & 0 & 0 & 0 & 0 & 0 & 1 & & & 2 \\
\hline $\begin{array}{ll}3 & \text { Pegawaial-3 } \\
\end{array}$ & 0 & 0 & 0 & $\cdot 1$ & 0 & 0 & 1 & 0 & .1 & 0 & 0 & 1 & & & 2 GAP \\
\hline 4 Pegawai-4 & 1 & 0 & 0 & 0 & $\cdot 1$ & 0 & 0 & 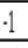 & 1 & 0 & 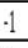 & 0 & & & 2 \\
\hline $5 \quad$ Pegawal.5 & 0 & 1 & 0 & $\cdot 1$ & 0 & 0 & 1 & 1 & 1 & 0 & 0 & 0 & 2 & & 2 \\
\hline
\end{tabular}
Sumber: Hasil Pengolahan (2016)

\section{Konversi Kenilai Bobot}

Untuk mengkonversi nilai gap kedalam nilai bobot yang sudah ditentukan, menghasilkan seperti table 6, dibawah ini.

\section{Tabel 6. Tabel Konversi}

\begin{tabular}{|c|c|c|c|c|c|c|c|c|c|c|c|c|c|c|c|c|c|}
\hline \multirow[b]{2}{*}{ No } & \multirow[b]{2}{*}{ Kode Pegawai } & \multicolumn{5}{|c|}{ Sikap Kerja } & \multicolumn{3}{|c|}{ Kecerdasan } & \multicolumn{4}{|c|}{ Prestasi Kerja } & \multicolumn{3}{|c|}{ Pendidikan } & \\
\hline & & $\begin{array}{l}\text { SK1 } \\
\text { (A) }\end{array}$ & $\begin{array}{l}\text { SK2 } \\
\text { (B) }\end{array}$ & $\begin{array}{l}\text { SK3 } \\
\text { (C) }\end{array}$ & $\begin{array}{l}\text { SK4 } \\
\text { (D) }\end{array}$ & $\begin{array}{l}\text { SK5 } \\
\text { (E) }\end{array}$ & & $\begin{array}{l}\text { K2 } \\
\text { (G) }\end{array}$ & $\begin{array}{l}\mathrm{K} 3 \\
\text { (H) }\end{array}$ & $\begin{array}{l}\text { PK1 } \\
\text { (I) }\end{array}$ & & & & & $\begin{array}{l}\mathrm{P} 2 \\
\text { (N) }\end{array}$ & & \\
\hline 1 & Pegawai-1 & 3 & 2 & 4 & 3 & 3 & 3 & 3 & 2 & 4 & 3 & 3 & 4 & 4 & 3 & 3 & \\
\hline 2 & Pegawai-2 & 2 & 3 & 3 & 4 & 2 & 2 & 3 & 3 & 3 & 3 & 3 & 4 & 4 & 4 & 3 & \\
\hline 3 & Pegawai-3 & 3 & 3 & 3 & 2 & 3 & 3 & 4 & 3 & 2 & 3 & 3 & 4 & 4 & 4 & 3 & \\
\hline 4 & Pegawai-4 & 4 & 3 & 3 & 3 & 2 & 3 & 3 & 2 & 4 & 2 & 2 & 3 & 4 & 3 & 3 & \\
\hline 5 & Pegawai-5 & 3 & 4 & 3 & 2 & 3 & 3 & 4 & 4 & 4 & 3 & 3 & 3 & 4 & 3 & 3 & \\
\hline & lilai Standar & 3 & 3 & 3 & 3 & 3 & 3 & 3 & 3 & 3 & 3 & 3 & 3 & 1 & 1 & 1 & \\
\hline 1 & Pegawai-1 & 0 & -1 & 1 & 0 & 0 & 0 & 0 & -1 & 1 & 0 & 0 & 1 & 3 & 2 & 2 & \\
\hline & Pegawai-2 & -1 & 0 & 0 & 1 & -1 & -1 & 0 & 0 & 0 & 0 & 0 & 1 & 3 & 3 & 2 & \\
\hline & Pegawai-3 & 0 & 0 & 0 & -1 & 0 & 0 & 1 & 0 & .1 & 0 & 0 & 1 & 3 & 3 & 2 & \\
\hline & Pegawai-4 & 1 & 0 & 0 & 0 & -1 & 0 & 0 & -1 & 1 & 0 & -1 & 0 & 3 & 2 & 2 & \\
\hline & Pegawai-5 & 0 & 1 & 0 & -1 & 0 & 0 & 1 & 1 & 1 & 0 & 0 & 0 & 3 & 2 & 2 & \\
\hline \multicolumn{18}{|c|}{ KONVERSI KE BOBOT } \\
\hline & gawail-1 & 4 & 3.5 & 4.5 & 4 & 4 & 4 & 4 & 3.5 & 4.5 & 4 & 4 & 4.5 & 2.5 & 5 & 5 & \\
\hline & Pegawai-2 & 3.5 & 4 & 4 & 4.5 & 3.5 & 3.5 & 4 & 4 & 4 & 4 & 4 & 4.5 & 2.5 & 2.5 & 5 & \\
\hline & Pegawai-3 & 4 & 4 & 4 & 3.5 & 4 & 4 & 4.5 & 4 & 3.5 & 4 & 4 & 4.5 & 2.5 & 2.5 & 5 & \\
\hline & Pegawai-4 & 4.5 & 4 & 4 & 4 & 3.5 & 4 & 4 & 3.5 & 4.5 & 4 & 3.5 & 4 & 2.5 & 5 & 5 & \\
\hline 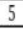 & Pegawail-5 & 4 & 4.5 & 4 & 3.5 & 4 & 4 & 4.5 & 4.5 & 4.5 & 4 & 4 & 4 & 2.5 & 5 & 5 & \\
\hline
\end{tabular}

Sumber: Hasil Pengolahan (2016)

E. Perhitungan dan Pengelompokan Core Factor (NCF) dan Secondary Factor (NSF) 
Untuk menghitung dan mengelompokan Core Core Factor (NCF) dan Secondary Factor (NSF), dengan menggunakan rumus berikut:

$N C F=\frac{\sum N C}{\sum I C} \quad N S F=\frac{\sum N C}{\sum I S}$

Keterangan:

$\mathrm{NCF} \quad$ : Nilai rata-rata core factor

NC : Jumlah total nilai core factor

IC : Jumlah item core factor

IS : Jumlah item secondary factor

Tabel 7. Hasil CF dan SF Sikap Kerja

\begin{tabular}{ccccc}
\hline No & $\begin{array}{c}\text { Kode } \\
\text { Pegawai }\end{array}$ & $\begin{array}{c}\text { Core } \\
\text { Factor }\end{array}$ & $\begin{array}{c}\text { Secondary } \\
\text { Factor }\end{array}$ & N1 \\
\hline 1 & $\begin{array}{c}\text { Pegawai- } \\
1\end{array}$ & 4.00 & 4.00 & 4.00 \\
\hline 2 & $\begin{array}{c}\text { Pegawai- } \\
2\end{array}$ & 3.83 & 4.00 & 3.90 \\
\hline 3 & $\begin{array}{c}\text { Pegawai- } \\
3\end{array}$ & 4.00 & 3.75 & 3.90 \\
\hline 4 & $\begin{array}{c}\text { Pegawai- } \\
4\end{array}$ & 4.17 & 3.75 & 4.00 \\
\hline 5 & $\begin{array}{c}\text { Pegawai- } \\
5\end{array}$ & 4.17 & 3.75 & 4.00 \\
\hline Sumber: Hasil Pengolahan (2016) &
\end{tabular}

Tabel 8. Hasil CF dan SF Kecerdasan

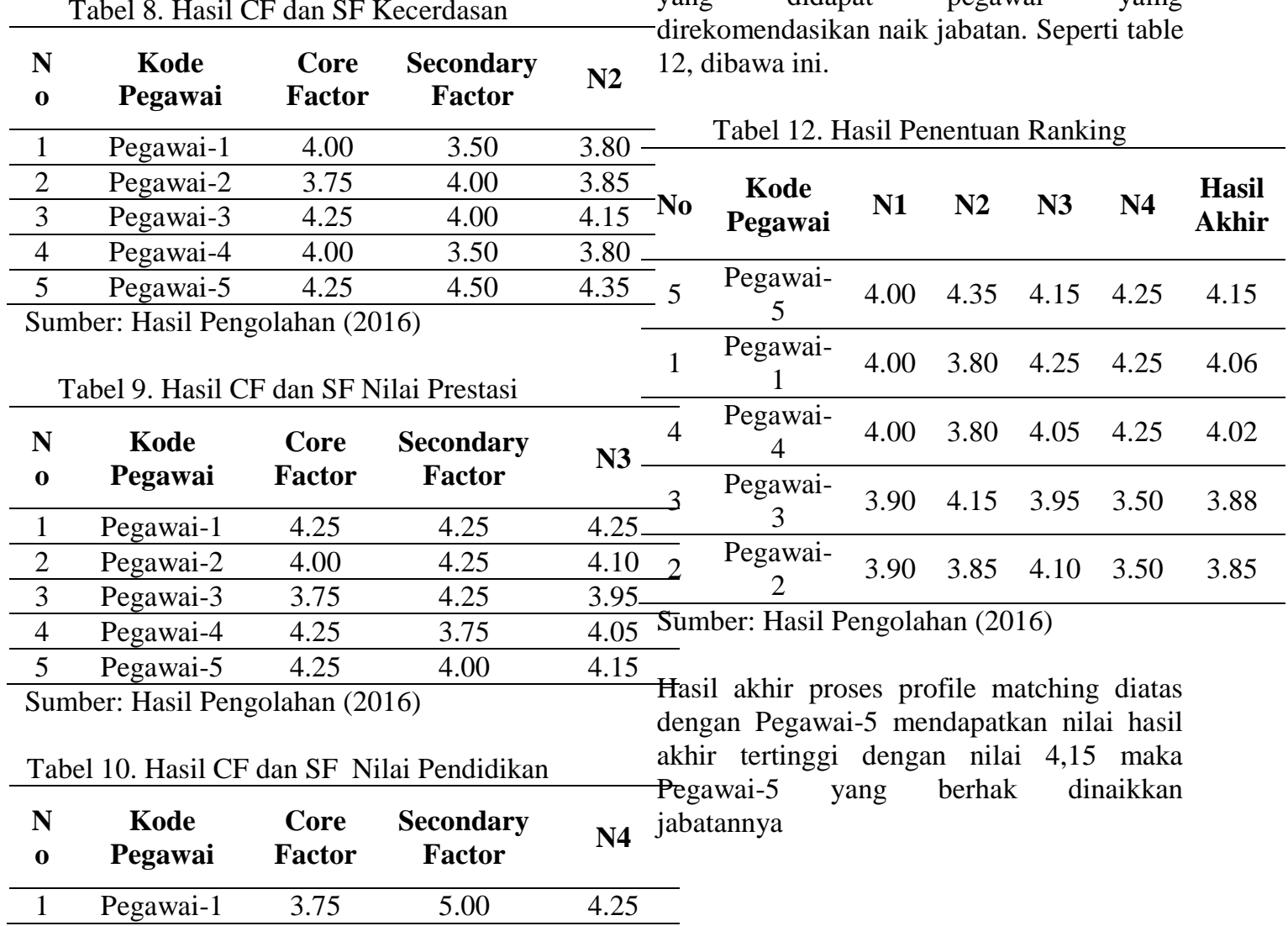

\begin{tabular}{rrrrr}
\hline 2 & Pegawai-2 & 2.50 & 5.00 & 3.50 \\
\hline 3 & Pegawai-3 & 2.50 & 5.00 & 3.50 \\
\hline 4 & Pegawai-4 & 3.75 & 5.00 & 4.25 \\
\hline 5 & Pegawai-5 & 3.75 & 5.00 & 4.25 \\
\hline
\end{tabular}

Sumber: Hasil Pengolahan (2016)

F. Penentuan Ranking

Untuk mengkonversi nilai gap kedalam nilai bobot yang sudah ditentukan, menghasilkan seperti table 11, dibawah ini.

Tabel 11. Hasil Penentuan Ranking

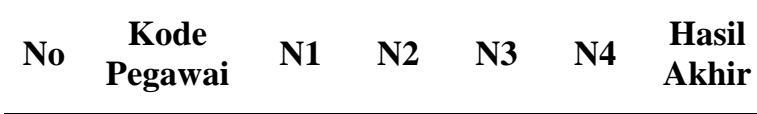

$1 \quad \begin{array}{ccccccc}\text { Pegawai- } & 4.00 & 3.80 & 4.25 & 4.25 & 4.06\end{array}$

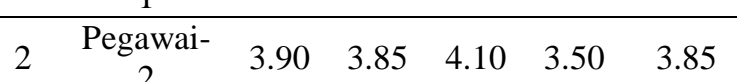

\begin{tabular}{lccccccc}
\hline & 2 & 3.90 & 3.85 & 4.10 & 3.50 & 3.85 \\
3 & $\begin{array}{c}\text { Pegawai- } \\
3\end{array}$ & 3.90 & 4.15 & 3.95 & 3.50 & 3.88
\end{tabular}

4 Pegawai- $4.00 \quad 3.80 \quad 4.05 \quad 4.25 \quad 4.02$

5 \begin{tabular}{lcrrrrr}
\hline & Pegawai- & 4.00 & 4.35 & 4.15 & 4.25 & 4.15
\end{tabular}

Sumber: Hasil Pengolahan (2016)

Setelah penentuan ranking pegawai mana yang berhak untuk naik jabatan. Berikut akah diurutkan berdasarkan nilai tertinggi yang didapat pegawai yamg direkomendasikan naik jabatan. Seperti table 


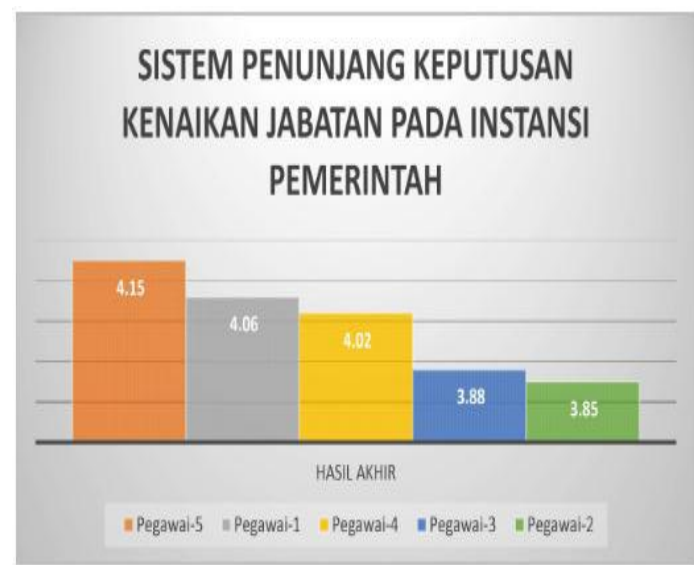

Sumber: Hasil Pengolahan (2016)

Gambar 1. Grafik Hasil Keputusan Kenaikan Jabatan Pada Instansi Pemerintah

\section{PENUTUP}

Dalam penelitian mengenai Sistem Penunjang Keputusan Kenaikan Jabatan Pada Instansi PemerintahDengan Metode Profile Matching, maka peneliti menarik kesimpulan yang berdasarkan paparan dari bahasan pada bab sebelumnya, yaitu: 1) Terdapat 15 (Lima Belas) kriteria dalam menentukan pegawai untuk kenaikan jabatan dari semua aspek yang terkait dengan uraian sebagai berikut: a) Dari aspek sikap kerja : kesetiaan, tanggung jawab, kejujuran, ketaatan dan kerjasama

Dari aspek kecerdasan : prestasi kerja, prakarsa, dan kepemimpinan. b) Dari aspek prestasi kerja: kecakapan, ketrampilan, pengalaman, dan kesungguhan. c) Dari aspek pendidikan: Pendidikan terakhir, kemampuan dan lama bekerja

2) Hasil penelitian dari perhitungan Profile Matching menyatakan bahwa alternatif yang terpilih dan paling sesuai dengan kriteria adalah pegawai-2 (P2) dengan hasil Profile Matching yang diperoleh dari kuesioner oleh 3 responden yang memberikan jawabannya dihitung dan di dapat hasil akhir bahwa Pegawai-5 (P5) unggul 4,15 berbanding dengan pegawai-1 (P1) sebesar 4,06, pegawai-4 (P4) dengan nilai 4,02, pegawai3 (P3) sebesar 3.88, dan pegawai-2 (P2) sebesar 3,85. 3) Dalam lembar DP3 Instansi
Pemerintah, faktor utama yang paling di utamakan adalah faktor Kesetiaan pada perusahaan. Metode Profile Matching dapat membantu Instansi khusunya untuk menentukan beberapa persoalan khususnya mengenai kenaikan jabatan.

\section{DAFTAR PUSTAKA}

Adhar Deny, 2014. Sistem Pendukung Keputusan Pengangkatan Jabatan Karyawan pada PT. Ayn dengan Metode Profile Matching. Medan : STMIK Potensi Utama.

Ananta P.W, dan Sri winiarti, 2013. Sistem pendukung keputusan dalam penilaian kinerja pegawai untuk kenaikan jabatan pegawai menggunakan metode GAP Kompetensi (Studi Kasus Perusahaan Perkasa Jaya Compuretail). Yogyakarta : Program Sarjana Teknik Informatika. Universitas Ahmad Dahlan.

Hartatik.2013. Analisis dan perancangan seleksi pemilihan pegawai untuk suatu jabatan menggunakan Metode Profile Matching. Yogyakarta : Manajemen Informatika STMIK AMIKOM Yogyakarta.

Kusrini,2007, Konsep dan Aplikasi Sistem Pendukung Keputusan Yogyakarta:C.V Andi Offset.

Muqtadir Asfan, dan Irwan Purdianto, 2013. Sistem Pendukung Keputusan Kenaikan Jabatan Menggunakan Metode Profile Matching (Studi Kasus di PT.Industri Kemasan Semen Gresik). Yogyakarta : Teknik Informatika. Universitas PGRI Ronggolawe Tuban, Indonesia.

Sugiyono,2009, Metode Penelitian Kuantitatif Kualitatif dan R\&D,Bandung: Alfabeta CV. 